DOI: $10.20472 / S S 2015.4 .1 .006$

\title{
CORPORATE SOCIAL RESPONSIBILITY: REWRITING THE RELATIONSHIP BETWEEN BUSINESS AND SOCIETY
}

\section{AYA MOHAMED SAFWAT}

\begin{abstract}
:
The relationship between business and society has witnessed a dramatic change in the past few years. Globalization, ethical consumerism, environmental concerns, strict government regulations, and growing strength of the civil society, are all factors that forced businesses to reconsider their role in society; accordingly there has been a surge of notions that tries to explain this new complex relation between business and society. This paper aims at accentuating this evolving relation by focusing on the concept of corporate social responsibility (CSR). It differentiates between CSR and other related concepts such as business ethics and corporate philanthropy. It analyzes the different arguments in the CSR debate, pinpoints mechanisms adopted by businesses in carrying out their social responsibilities, and concludes with the link between corporate social responsibility and sustainable development.
\end{abstract}

\section{Keywords:}

Business Ethics, Corporate Philanthropy, Corporate Citizenship, Corporate Social Responsibility, Sustainable Development, Corporate Social Development

\section{Authors:}

AYA MOHAMED SAFWAT, Faculty of Economics and Political Science, Future University in Egypt, Egypt, Email: aya.safwat@fue.edu.eg

\section{Citation:}

AYA MOHAMED SAFWAT (2015). Corporate Social Responsibility: Rewriting the Relationship between Business and Society. International Journal of Social Sciences, Vol. IV(1), pp. 87-99.,

10.20472/SS2015.4.1.006 


\section{Introduction}

Identifying the role and responsibilities of business in society has been the quest and concern of many scholars for decades. In recent years the relationship between business and society had witnessed a massive transformation from the traditional classical view of business asprofit maximizing economic agentsto a more ethical outlook that analyzes the greater impact of business on society.

A number of factors havecontributedin shaping the new relation between business and society. Globalization imposed tremendous pressure on businesses worldwide to enhance their global image. Rising power of consumers forced businesses to become more conscious of the destructive effect of their actions, adding to that the growing trend of ethical consumerism which imposes both an opportunity and a threat to businesses worldwide. Growing concerns of the environmental footprint of business activities, as well as the growing strength of civil society activists in many countries have made it impossible for businesses to carry out their activities with the liberty they enjoyed before. Stricter government regulations and the impact of standardization on brand image, these are all factors that imposed a great burden on businesses. As a result, a revision of the relationship between business and society became inevitable. Hence, there has been a surge of notions like business ethics, corporate philanthropy, corporate citizenship, corporate social responsibility... etc. that try to scrutinize this complex relation.

This paper examines the link between business ethics and corporate social responsibility in defining the relation between business and society; it highlights the difference between corporate philanthropy and corporate social responsibility, through adopting an ethical approach in analyzing CSR, pinpointing itsguiding principles, various techniques and mechanisms, and its relation to sustainable development.

\section{Business Ethics and Corporate Social Responsibility}

Many notions such as Business Ethics, Corporate Philanthropy and Corporate Social Responsibility, are sometimes used interchangeably to describe the relation between business and society, although each has a different aim. According to Ferrell, Fraedrich, and Ferrell (2011) business ethics are the principles and standards that guide acceptable behavior in business organizations, whereas theextent of acceptability of business behavioris determined by a variety of entities including customers, competitors, government regulators, interest groups, and the public, thus it relates to society's evaluation of an action as right or wrong. Common business problems such as defective products, bribery, and accounting fraud exist due to the lack of or decline in business ethics. Although the judgment on business actionsis based on each individual's moral principles and valuesthis ethical perception of business stresses on the fact that there has been a radical change in society's view of businesses.

Although the terms corporate social responsibility and business ethics are used interchangeably, they have different meanings; whereas corporate social responsibility (CSR) tries to analyze the extended socio-economic role of business in society. CSR is a broader concept in a sense that it is concerned-from a stakeholder perspective- 
with the impact of business's activities on society. Thus, CSR is a stakeholder oriented notion that focuses primarily on voluntary commitments of an organization regarding both its internal and external issues, which are determined by the business's understanding and acknowledgement of its moral responsibilities concerning the impact of its activities on society (Maon, Lindgreen, and Swaen, 2010).

3.

Cor

porate Philanthropy vs. Corporate Social Responsibility

Albeit the fact that the responsibility of business is well acknowledged from theoretical and practical perspectives, there remains no general agreementon what CSR actually means ( $\mathrm{Lin}-\mathrm{Hi}, 2010)$; thus there is a prominent argument that corporate philanthropy (CP) is synonyms with Corporate Social Responsibility. This view which has prevailed for years contributed to the underutilization of CSR.

Corporate Philanthropy is the act of performing charitable or benevolent actions by business which depends on the interests of corporate managers at a particular point in time; therefore, it concentrates on one stakeholder. In most cases philanthropy is devoted to items that governments should be doing (Hopkins, 2006). Philanthropy is a common act, in many countries; businesses donate to schools, hospitals, or charity organizations. On the other hand CSR is more than corporate philanthropy as strategic CSR programs allow businesses to learn from the projects they invest in and make use of that knowledge to build their own capability, while improving social or environmental conditions (Heslin and Ochoa, 2008).

Lin-Hi (2010) argues that carrying out corporate social responsibility as corporate philanthropy is misleading as CSR has more to it than just philanthropy. Good deeds towards society have prevailed for many years, corporate giving, and other charitable activities are not a new idea. Hence, equating corporate social responsibility with philanthropic activities renders CSR a new term for an old idea. Besides, a philanthropic approach to CSR focuses on how to use businesses resources beyond the core business activities without inquiring how the resources or funds were made, which entails a separation of daily business operations and responsibility. But how profits are made in the first place is a relevant query, as it is insensible to label a corporation as responsible just because it is renowned for its philanthropic activities, while that exact same corporation is involved in unethical behavior such as cheating customers or bribing the government. Thus, a philanthropic approach to CSR does not provide a criterion for responsible profit-making.

Evidently CSR is not only concerned with philanthropy, as CSR is a system wide concept that involves all the stakeholders of the corporation (Hopkins, 2006).From a stakeholder perspective the accountability of business is extended to a wide spectrum of people starting from internal stakeholders such as employees and customers all the way to external stakeholder such as the environment. In addition, CSR is sustainable in a sense that its practices become an integral part of corporations' operations. In assessing the significance of both CP and CSR from an ethical outlook CSR is more important as it establishes the fact that business is 
behaving ethically in all its activities; so, in its broader sense it encompasses corporate philanthropy.

There is no formal definition of CSR. However, the notion of CSR became imperative in the business context after Howard Bowen in 1953 labeled it as social obligation of business, the obligations to practice policies, take decisions, and adopt actions that are desirable according to the objectives and values of the society (Thomas and Nowak, 2006). Ever sense, there were numerous attempts to produce a formal definition of CSR, one of which wasformulated by the European Commission in its green paper as it labeled CSR as "Being socially responsible means not only fulfilling legal expectations, but also going beyond compliance and investing more into human capital, the environment and the relations with stakeholders" (European Union, Commission of the European Communities, 2001, p.6).

A comprehensive definition of CSR was given by Carroll, who stated that "The social responsibility of business encompasses the economic, legal, ethical, and discretionary expectations that society has of organizations at a given point in time" (Carroll, 2006, p. 16). This definition regards business from the broad stakeholder rather than shareholder perspective, thus, these responsibilities are a reflection of the expectations placed on any business by its stakeholders and society as a whole (Carroll and Shabana, 2010).

According to Carroll (1991) the social responsibilities of businesses can be depicted as a pyramid which consists of the four responsibilities stated in his definition of CSR: economic, legal, ethical, and philanthropic-formerly referred to as the discretionary responsibility-. For a business to be labeled as socially responsible the four above mentioned responsibilities must be fulfilled in harmony. The economic responsibility entails that businesses are identified as the basic economic units in the society so they have the responsibility of producing valuable goods and services demanded by the society and selling them to acquire profits, reassuring that economic viability is for the benefit of both the corporation and the society because it helps the continuity of the economic system. The legal responsibility emphasizes society's expectation of businesses to fulfill their economic role while obeying the law set by society's legal institutions. The ethical responsibility extends beyond obedience of law; it represents the kind of corporate behavior and activities that adhere to the ethical norms of consumers, employees, and the society as a whole. The philanthropic responsibility represents the voluntary roles that business practice to be a good corporate citizen from the point of view of the society through promoting human welfare (Carroll, 2006; Carroll, 1991).

In view of Carroll's definition of CSR, businesses that carry out their activities in a socially responsible manner become corporate citizens. The notion of corporate citizenship (CC) is gaining momentum, each year businesses are ranked according to their success in proving their good citizenship. The fact that the view of firms is changing from purely business entities to the idea of citizenship magnifies the mounting role of businesses in society. It is becoming inevitable that businesses are required to act as good corporate citizens by abiding to codes of business integrity in dealing with all related stakeholders (Ulrich, 2013). 
There are three views of corporate citizenship according to Matten and Crane (2003).The first is a limited view where corporate citizenship is driven by self-interest of the corporation and is equivalent to corporate philanthropy. The Second view is the same as CSR, where corporate citizenship is defined as CSR with four aspects (economic, legal, ethical, and philanthropic), while the third extended view of CC is defined as "corporate citizenship describes the role of the corporation in administering citizenship rights for individuals" (Matten and Crane, 2003, p. 13), from that view businesses practice liberal citizenship through three different roles: the role of "provider of social rights", the role of "enabler of civil rights" and the role of a "channel of political rights". It is in society's best interest that businesses move from the limited view to the second and third views of CCto really benefit from their potentials.

\section{The CSR Debate}

In spite of the rising awareness of the importance of CSR among businesses it remains a debatable issue. Most of the voices refuting CSR are based on the argument of Milton Friedman (1970) representing the conservative neo-liberal view of CSR. According to this argument, the social responsibility of business begins and ends with increasing profits, where the self-interested actions of millions of participants in free markets shouldlead to positive outcomes for the society and hence taking on social and moral issues is not economically feasible (Carroll, 1991; Friedman, 1970). In view of that, businesses should focus on earning and maximizing profits for their shareholders and leave social issues to others as CSR is an unnecessary distraction and corrupts the logic and wealth creating rules of capitalism, to the extent that it is viewed as a new type of socialism in disguise. In addition, businesses executives are incapable of dealing with and solving problems in the society. Moreover, there is a lack of integration of CSR activities and agenda in the culture of business and on all levels of management to the extent that it is sometimes viewed as irrelevant and counterproductive to businesses goals(Carroll and Shabana, 2010; Lunheim, 2005; Anderson, 1989).Other major critique to CSR has been evolving around the vagueness of the concept itself, and the misuse of CSR as a public relations tool without any real impact on the society (Hopkins, 2006).

However, it can be argued that CSR opponents have ignored Friedman's main rationale in explaining the role of business in society, as he explained that making profits for the shareholders is the primary responsibility of business but in order to do so business had to comply with the basic rules of society, both those embodied in the law and those embodied in ethical custom. Thus, his definition of business responsibilities entailed abiding to both the legal and ethical norms of society whichare similarto the legal and ethical responsibility pointed by Carroll in his definition of CSR.

On the other hand, CSR advocates have presented several arguments stressing upon the importance of CSR. From an ethical perspective, the fact that there is a great interdependence between business and society as businesses rely on society's tangible and intangible assets, postulates that the purpose of business is not only to make profit but how to use this profit to build a better society.Besides, 
corporations create many social problems so they should help in solving them (Anderson, 1989).

From a self-interest perspective CSR supporting arguments emphasizes on how CSR practices have a positive outcome on the business itself, as they enhance business reputation and minimize the risk of corporate scandals that reduce both public trust of businesses and public confidence in the ability of the regulatory bodies to control them. CSR also helps in attracting, motivating, and retaining employees, as well as improving access to finance. Any business with a long-run perspective of its goals, behave in an ethical manner in the present to guarantee a favorable operating environment in the future. Accordingly, businesses ought to look beyond the short term bottom line perspective and realize that current investment in the society will yield its gains in the future. Moreover, businesses with good CSR policies have better relation with governments and the civil society which gives them a competitive edge over their competitors especially in the case of multinational corporations which depend heavily on outsourcing, hence, CSR help businesses anticipate and avoid government regulation (Carroll and Shabana, 2010; Haigh and Jones, 2007; Hopkins, 2006; Anderson, 1989). In addition, businesses that adopt CSR practices are fulfilling the demands of the public of the extended role of business toward their stakeholders (Carroll and Shabana, 2010). Furthermore, CSR takes account of the rising trend of ethical consumerism which accentuates the increasing influence of consumers who can afford to pick and choose the products they buy (Heslin and Ochoa, 2008).

\section{Stages and Principles of CSR}

Even though businesses are becoming more aware of their social responsibilities, they are unable to transform overnight to adapt to society's expectations. Consequently, businesses approach towards CSR varies between two extremes either of dismissing the notion entirely or promoting best practices out of genuine belief that CSR is an integral part of their business activities. According to Zadek (2004) most of businesses go through five stages of their transformation to become good corporate citizens and developing a sense for CSR. First, the "defensive" stage, in which business is unexpectedly criticized on their actions either from the media and civil activists or from direct stakeholders such as customers, employees, and investors. In this case the business's legal and communications teams focusing on short term sales respond by either rejecting the allegations or denying the links between the company's practices and negative outcomes. Second, the "compliance" stage, where business feels the necessity to develop, monitor, and publicize a corporate policy to counter criticism. In that sense, compliance is perceived as a cost associated with business; through this stage businesses aim at creating value through protecting theirreputation and reducing the risk of legal action. In the third "managerial" stage, business realizes that compliance or a public relations strategy is not sufficient to solve the long-term problem it faces. Thus, managers carry the responsibility for dealing with the problem and finding solutions; thus responsible business practices become an integral part of businesses' operations. During the fourth "strategic" stage, businesses learn that by restructuring their strategies to 
concentrate on responsible business practices and integrating societal needs, they are given a competitive edge and add to their long-term success. In the fifth "civil" stage, businesses encourage collective action to address the concerns of the society, and some companies have anextended outlook and consider the future role of business in society.

Whether a business goes through all stages toreach the civil stage or remain in the early stages depends on a number of factors including the culture within the organization itself, the surrounding environment, the severity of the competition itfaces, the strength of the stakeholders, the power of the civil society and the media, the role of the government...etc.

As CSR has no manual to be implemented by business all over the world, it is increasingly difficult for business to pinpoint the most important issues pertaining to CSR. Most businesses that begin to address their social responsibilities become perplexed on how to approach those responsibilities. Heslin and Ochoa (2008) argue that there are seven strategic principles that can help guide businesses indeveloping CSR strategies, mainly focusing on two main dimensions, the human factor and business operations; through protecting labor welfare, cultivating needed talent, involving customers, reducingbusinesses' environmental footprint, greening the supply chain, profiting from by-products, and developing new markets.

In addition, many International Organizations have helped in promoting CSR framework or guiding principles for businesses, such as the European Union, the United Nations, and the Organization for Economic Cooperation and Development (OECD). According to the OECD guidelines for multinational enterprises ${ }^{1}$ businesses ought to respect the internationally accepted human rights of people affected by their activities, encourage local capacity building in cooperation with the local community, create employment opportunities and facilitate training opportunities for employees to assist in human capital formation. Moreover, businesses should contribute to economic, environmental and social progress of society with the aim of achieving sustainable development. Furthermore, businesses should guarantee the disclosure of timely and accurate information on all material matters regarding their activities, structure, financial situation, performance, ownership and governance (OECD, 2011). Moreover, the United Nations launched the UN Global Compact (UNGC) ${ }^{2}$, a strategic policy initiative for businesses which encompasses ten principles related to human

${ }^{1}$ These are recommendations addressed by governments to multinational enterprises and applicable to domestic firms alike. They encompass voluntary principles and standards for responsible business conduct consistent with applicable laws and internationally recognized standardsthat aim at: guaranteeing the harmonization of business operations with government policies, strengthening the basis of mutual confidence between business and the societies in which they operate, improving the foreign investment climate, and enhancing the contribution to sustainable development made by multinational enterprises.

${ }^{2}$ The UNGC is considered the world's largest voluntary corporate citizenship initiative with the goal of supporting CSR application around the world to reach a more sustainable and inclusive global economy. 
rights, labor, environment, and anti-corruption issues. (United Nations, Global Compact Office, 2009).

\section{CSR Implementation Techniques}

CSR is sometimes viewed as a publicity stunt to improve businesses brand image without real impact on society. That can mainly be attributed to the fact that there is no unique way in which business carries its social responsibility towards society as those responsibilities depend on a number of factors including: the size and aim of the business, the degree of integration of CSR in the organization's culture, the country it operates in, and the nature of the industry itself.

As noted by Griffin and Prakash (2010) businesses employ four common mechanisms to fulfill their CSR policies. First: unilateral acts where businesses donate resources to a variety of corporate initiatives, which might be regular or irregular investments. Second, partnerships where business enter into contractually based relationships either with governments or non-governmental organizations to achieve a certain objective, which allows teaming up and coordinating skills and expertise in specific areas. Third, businesses establish foundations with the aim of creating a longterm institutional system to support sustainable development activities in society. Fourth, voluntary programs that encourage businesses to take on beyond compliance policies that either lead to positive externalities or reduce negative externalities associated with their activities.

As CSR implementation mechanisms vary, there is also a variety of CSR initiatives. CSR initiatives can target specific groups such as employees by focusing on enhancing their economic, social, and political opportunities, and consumers through presenting new product features, they can also focus on the supply chain to secure socially responsible inputs, or they could be directed for development purposes focusing on improving the human and social capital of societies (Griffin and Prakash, 2010). Kotler and Lee (2005) classified business' initiatives towards society into six types: cause related marketing, cause promotion, corporate social marketing, corporate philanthropy, community volunteering, and socially responsible business practices. First, cause related marketing (CRM) wherethe responsibility of giving back to society is related to the volume of sales, as in (CRM) corporations assign a certain percentage of revenues to a specific cause based on product sales for an announced period of time, for a specific product. Even though this strategy is becoming more and more popular and is used by businesses worldwide mainly because it is viewed by managers as win-win-win situation where the target of increasing sales is tied to a social cause, this might not always be the case as there are risks pertaining to CRM which might lead to its failure of in producing a win situation for all related parties (Hemat and Yuksel, 2014). Second, in the case of cause promotionsbusinessesindividually or in partnerships with others support a social cause by increasing community awareness through providing funds, in-kind contributions, or through supporting fundraising, or volunteer recruitment. This type depends on managers' preferences and views of most pressing social problems. Third, corporate social marketing initiatives which focus mainly on the role of businesses in inducing 
behavioral change in society aiming to improve public health, safety, environmental or community wellbeing. Fourth, incorporate philanthropy businesses make direct grants or in kind contribution to support a charity or a cause.This type used to be the most sought initiative by businesses worldwide; however, under the increasing amount of pressure from stakeholders, businesses adopt other CSR initiatives such as the fifth type community volunteering wherebusinesses encourage their employees, retail partners,...etc to volunteer their time to support local community organizations and causes which proves to be an efficient technique in the sense that it serves two purposes. First, it creates a sense of belonging to the business as it is viewed by the stakeholders especially the employees as an ethical entity. Second, it creates a sense of solidarity with the society. The last type, socially responsible business practice refer to discretionary business practices and investments to support social causes with the aim of enhancing community well-being and improving and protecting the environment. The last type is the most relevant tothe current context in a sense that the primary aim of societies now is to involve businesses to take part in their continuing pursuit of development, this initiative allows society to identify its most pressuring social problems and benefit from businesses financial and technical expertise to address those problems with the aim of contributing to sustainable development.

\section{CSR and Sustainable Development}

The link between CSR and sustainable development can be found in the CSR literature that includes theories explaining the concept from different perspectives. As suggested by Garriga and Mele (2004), CSR theories can be classified into four main categories: Instrumental, Political, Integrative, and Ethical.The ethical categorycomprises four approaches that explain the surge of CSR concept. The universal rights approach focuses on the role of CSR in implementing human rights. The common good approach proposes that business as an integral part of any society has an obligation to be a positive actor to the wellbeing of the society. The normative stakeholder theoryproposes that a socially responsible business should pay attention to the legitimate interests of all appropriate stakeholders and balance the multiplicity of those interests. Finally, the sustainable development approach views CSR as a tool that aims at and leads to development (Garriga and Mele, 2004).

Sustainable development gained momentum after Brundtland report defined it as the challenge of meeting the needs of today without compromising the ability of future generations to meet their needs. This concept postulates both equity and justice within and between generations and sheds the light on the long run goals for human beings (Hauff, 2007). Sustainable development gained popularity as it incorporates not only private economic interests, but also environmental concerns and people needs which can be achieved through adopting thetriple bottom line (Ulrich, 2009). Accordingly every action taken by businesses today must be scrutinized to ensure the right of future generations.

Sound CSR policies entail that businesses are substituting cut throat beggar thy neighbor policies with a holistic approach towards the well-being of the society as 
a whole by considering the implications of their actions on all levels. As a result, businesses transform from reactive to proactive CSR through substituting their conventional bottom line with a triple bottom line for "people, planet, and profit", thus becoming a sustainable enterprise that contributes to sustainable development (Aguilera et al., 2007, Hart and Milstein, 2003).

The sustainable development approach for CSR requires an analysis of which business activities can be labeled as developmental. Hopkins (2006)proposed that there are three types of business initiatives that lead to development, the classification depends on the magnitude of the impact of those initiatives on society, moving from the least to the most influential respectively. The first type is development philanthropy where business donates to support a certain good cause in a developing country. This type has increased dramatically in recent years. However; it remains to be a weak form of development as it suffers from majorobstacles such as lack of sustainability, lack of supervision and corruption, ultimately leading to its failure in fulfilling its intended purposes. Another drawback to this type is that as mentioned before in case of philanthropy in some cases the donations are merely an act of publicity, or a cover up for the real harm businesses do to society. The second type is development as a by-product of companies' actions where businessescreate new products for developing countries, or invest in a developing country to take advantage of human or natural resources. Although many products under this type enhance the life of people, the hidden aim of business isto take advantage of natural resources or cheap labor. The third type isactivities and anti-poverty initiatives that promote sustainable development. This type is the best form of involvement as it serves a dual purpose of contributing to the development process and helpingbusinesses in multiple ways by improving their reputation, reducing risk especiallyfor those operating in developing countries, as well as having along run trickle-down effect on businesses' bottom line. Moreover, there is an increasing trend to promote Corporate Social Development (CSD) which describes social actions outside the business that target all stakeholders with the aim of improving the wellbeing of people in developing countries (Hopkins, 2006).

\section{Conclusion:}

Notions such as CSR are evidence of the evolution of the relation between business and society, and the interconnectivity between them. It is a manifestation of the growing awareness that both of them rely on each other for survival. This paper highlights the changing relation and role of business in society through scrutinizing the concept of corporate social responsibility. It differentiates between CSR and other related concepts such as Business Ethics and Corporate Philanthropy.

CSR is a holistic concept that explains the relation between business and society. It is a solution for the equity vs efficiency dilemma in understanding the role of business in society. Viewing CSR as philanthropy is misleading as it entails a separation between daily business activities and corporate giving which is not theaim of CSR. Besides, this view does not reflect the full range of responsibilities and 
obligations of businesses towards society; it also restrains the power of CSR in producing positive sustainable change.

Although CSR is still a debatable issue, the supporting arguments in the CSR debate demonstrate the inevitability of integrating CSR in modern business context. Different principles and international initiatives have emerged to guide businesses on how to embrace their social responsibilities and achieve the triple bottom line. However, there still exists a huge divergence in CSR practices as it depends on the stage of compliance of businesses in addressing their social responsibility; there is also a disagreement on the way of implementing CSR activities;nevertheless,both foundations and voluntary programs are proving to be efficient tools in satisfying CSR objectives.

Businesses vary in the degree of acceptance and executionof their responsibilities; it remains the obligation of societies to guide businesses on their most pressing societal issues. Both Business and society should share the same vision of achieving sustainability. In point of that, CSR from an ethical approach serves as a moral guide for businesses. Sustainably driven CSR policies imply that businesses are moving towards achieving the extended view of corporate citizenship. It accentuates the link between CSR and sustainable development and highlights the transformation of businesses' aim from profit maximization to pursuing the triple bottom line.

Nonetheless, CSR remains underutilized, asmany CSR initiatives fail to serve their purpose due to lack of integration between business and society. Yet, there is a huge opportunity for countries especially developing ones to benefit from CSR initiatives by shifting the focus of businesses from corporate philanthropy to socially responsible activities that are directly linked to society's needs and demands. The evolution of CSR to CSD-a notion that reflects a more ethical developmental approach- where the aim of businesses is development in the first place, allows proper orientation and use of vast resources (both physical and human) employed by businesses in their CSR practices to developmental issues. Thus, a more rigorous approach on how to integrate societal needs to CSR programs is a must to practically demonstrate how CSR can serve as a tool that assists and leads to development.

\section{References}

Aguilera, R. V. (2007). Putting The S Back in Corporate Social Responsibility: A Multilevel Theory of Social Change in Organizations. Academy of Management Review. 32 (3). p. 836-863.

Anderson Jr., J.W. (1989) Corporate Social Responsibility: Guidelines for Top Management. Westport, Connecticut: Quorum Books.

Carroll, A.B. and Shabana, K. M. (2010), The Business Case for Corporate Social Responsibility: A Review of Concepts, Research and Practice International Journal of Management Reviews. p. 85-105. 
Carroll, A.B. (2006) Corporate Social Responsibility: A Historical Perspective, In Epstein, M. J. and Hanson, K.O. (eds.) The Accountable Corporation: Corporate Social Responsibility. Vol. 3. Westport Connecticut: Praeger.

Carroll, A.B. (1991) The Pyramid of Corporate Social Responsibility: Toward the Moral Management of Organizational Stakeholders.Business Horizons, 34 (4) (JulyAugust).p.225-235.

Hart, S. L. and Milstein M. B. (2003).Creating sustainable value.Academy of Management Executive.17 (2). P. 56-69.

Hauff, V. (2007). Brundtland Report: A 20 Years Update. Keynote Speech presented at the European Sustainability: Linking Policies, Implementation, and Civil Society Action conference. Berlin 07. June $3^{\text {rd }}-5^{\text {th }}$.

Hopkins, M. (2006) Corporate Social Responsibility and International Development: Is Business the Solution?.London: GBR: Earth Scan Publications Ltd.

European Union.Commission of the European Communities (2001) Green Paper: Promoting a European Framework for Corporate Social Responsibility.European Commission's Communication on Sustainable Development COM 18-7-2001. Brussels.

Ferrell, O.C., Fraedrich, J., and Ferrell, L. (2011) Business Ethics: Ethical Decision Making and Cases ( $8^{\text {th }}$ edition).USA: South-Western, Cengage Learning.

Friedman, M. (1970) The Social Responsibility of Business is to Increase its Profits. The New York Times Magazine. [Online].13 ${ }^{\text {th }}$ September. Available From: http://www.colorado.edu/studentgroups/libertarians/issues/friedman-socresp-business.html. [Accessed: 15th May 2014].

Garriga, E. and Mele, D. (2004) Corporate Social Responsibility Theories: Mapping the Territory, Journal of Business Ethics. 53. p. 51-71.

Griffin, J.J. and Prakash, A. (2010) Corporate Responsibility: Initiatives and Mechanisms, Business and Society.49 (1). p. 179-184.

Haigh, M. and Jones, M.T. (2007) A Critical Review of Relations between Corporate Social Responsibility Research and Practice.Electronic Journal of Business Ethics and Organization Studies.12 (1). p. 16-28.

Heslin, P.A. and Ochoa, J.D. (2008) Understanding and Developing Strategic Corporate Social Responsibility, Organizational Dynamics.37 (2). p. 125-144. 
Kotler, P.and Lee, N. (2005) Corporate Social Responsibility: Doing the Most Good for Your Company and Your Cause. New Jersey: John Wiley and Sons, Inc.

Lin-Hi, N. (2010) The Problem with a Narrow-minded Interpretation of CSR: Why CSR has Nothing to Do with Philanthropy, Ramon Llull Journal of Applied Ethics. p. 80-95.

Lunheim, R. (2005) Corporate Responsibility - in Good Company?. In NTNU Conference Navigating Globalization: Stability, Fluidity, and Friction, Trondheim, Norway, 4- 6 August 2005. p. 1-12.

Maon, F., Lindgreen, A. and Swaen, V. (2010) Organizational Stages and Cultural Phases: A Critical Review and a Consolidative Model of Corporate Social Responsibility Development, International Journal of Management Reviews, 12 (1) p. 20-38.

Matten, D. and Crane, A. (2003) Corporate Citizenship: Towards an Extended Theoretical Conceptualization.International Centre for Corporate Social Responsibility Research Paper Series.4.Nottingham University.

Mermod, A. Y. and Idowu S. O. (Eds) (2014). Corporate Social Responsibility in the Global Business World. Springer-Verlag: Berlin.

OECD (2011).OECD Guidelines for Multinational Enterprises, OECD Publishing.

Thomas, G. and Nowak, M. (2005) Corporate Social Responsibility: A definition.GSB Working Paper Series. 62.

Ulrich, P. (2013). Ethics and Economics. In: Zsolnai, L. (Ed.). Handbook of Business Ethics: Ethics in the New Economy. Bern: Peter Lang International Academic Publishers.

Ulrich, P. (2009).Civilizing the Market Economy: The Approach of Integrative Economic Ethics to Sustainable Development. Discussion Papers of the Institute for Business Ethics. 114.

United Nations. United Nations Global Compact Office. (2009) United Nations Global Compact Annual Review 2008. New York.

Zadek, S. (2004) The Path to Corporate Responsibility. In Harvard Business Review On Point Collection (2007). Harvard Business School Publishing Corporation, p. 36-44. 